\title{
Preferences in Business and Corporate Strategies: The Role of Personal Values
}

\author{
Hussein Ismail \\ Lebanese American University \\ E-Mail: hismail@lau.edu.lb
}

\begin{abstract}
This study explored the relationship between 24 personal values and strategic preferences. Data was collected from 137 participants. Through stepwise discriminant analysis, the data were analyzed to reveal that personal values do have a relationship with strategic preferences. In particular, the 'obedience' value was more distinctly related to customer-focused business strategies. 'Courtesy' was mostly associated with backward integration strategies, while 'adaptability' was more related to forward integration strategies. Finally, the findings of this study revealed that diversification strategies were not related to personal values.
\end{abstract}

Keywords: Strategy, Personal Values, Strategic Preferences, Business Strategy, Corporate Strategy

\section{INTRODUCTION}

Strategic decisions are vital in shaping the success of a firm (Eisenhardt \& Zbaracki, 1992; Hitt, Keats, \& DeMarie, 1998; Shivakumar, 2014). Decision makers have a strong influence on the strategic direction of the firm and make strategic choices regarding the direction of their corporations (Child, 1972). The term strategic choice 'is intended to be a fairly comprehensive term to include choices made formally and informally, indecision as well as decision, major administrative choices... as well as the domain and competitive choices more generally associated with the term strategy' (Hambrick \& Mason, 1984: 195). In other words, strategic choice involves the options that a decision maker faces concerning the type of strategies to be followed.

Despite the fact that managers make the final choices regarding a firm, decision making is a complex issue influenced by various forces in and outside the firm (Elbanna \& Child, 2007; Rahman \& De Feis, 2009). The state of the competition in 
the industry, managers' personal characteristics such as education, organizational characteristics, psychological factors, and ownership type can all have an impact on strategic decision making (see for example Hitt \& Tyler, 1991; Papadakis, Lioukas, \& Chambers, 1998; Lee, Newman, \& Price, 1999; Ashill \& Jobber, 2013). For the purposes of this paper, the focus will be placed on personal characteristics. According to the theory by Hambrick and Mason (1984) on managerial characteristics, two major groups of factors affect strategic choices: first, psychological, which includes the cognitive base, values, and personality, and second, observable characteristics. The latter includes factors such as age, education, and socio-economic roots. Whereas most of the studies have centered on the influence of observable characteristics on strategic choices (Bantel \& Jackson, 1989; Brouthers, Brouthers, \& Werner, 2000; Carpenter, Geletkanycz, \& Sanders, 2004), research on psychological dimensions is largely lacking (Lawrence, 1997; Peterson, Smith, \& Martorana, 2003).

Apart from a limited number of studies which explored the role of personality in strategic choices and behavior (e.g. Miller, Kets de Vries, \& Toulouse, 1982; Nadkarni \& Herrmann, 2010; Chatterjee \& Hambrick, 2007; Gupta \& Govindarajan, 1984; Peterson et al., 2003; Nadkarni \& Herrmann, 2010), much more research is needed to explore and understand the relationship between various psychological dimensions and strategic choices (Hambrick, 2007). As Nadkarni and Herrmann (2010: 1065) stated, 'prior studies have examined attributes that capture only a narrow slice of CEO personality (e.g., locus of control) or that, despite intuitive appeal, lack strong psychological and methodological grounding' (e.g., CEO hubris) (Hiller \& Hambrick, 2005: 298). However, to the author's knowledge, the relationship between personal values and both business and corporate strategies has not been explicitly studied in a published empirical paper. However, one exception is Kotey and Meredith (1997), who studied the relationship between values and business strategy in small businesses. However, their paper departs from this study in various ways, including the fact that the mentioned paper is exclusively concerned with the small-business domain and is more focused on the topic of entrepreneurial values. In addition, the conceptualization of strategy is different in that it is limited to proactive and reactive business strategies, while this research deals more with generic business strategies and examines both business and corporate strategies from an exploratory angle. Regardless of these differences, this research promises to contribute to the previous research that can help us further understand the link between personal values and strategies. As Finkelstein, Hambrick, and Cannella (2009) argued previously, little empirical research has been conducted on how personal values are converted into managerial action. This is unfortunate, given the theorized importance of personal values in strategic choices 
(Hambrick \& Mason 1984; Finkelstein, et al., 2009). While there have been several works on personal values and strategic choice, it follows that the overwhelming majority of the extant research has focused on theory and on the development of propositions (e.g. Pant \& Lachman, 1998; Hambrick \& Mason, 1984; Hambrick \& Brandon, 1988).

The aim of this study is to establish the extent to which personal values might influence decision makers' choices in business and corporate strategies. The research addresses the current gaps in the literature by contributing further to our understanding of the role of the psychological dimensions in general and personal values in particular in making strategic choices. Moreover, from a practical perspective, this research can help organizations in recruiting and selecting decision makers who fit with the strategy of the firm. Personal values are becoming increasingly important criteria in hiring practices (Dolan, Garcia, \& Richley, 2006). In particular, the paper has two main objectives. The first objective is to empirically explore whether personal values have an effect on personal choices in business and corporate strategy types. The second objective is to identify sets of personal values that match the preferred types of business and corporate strategies. In the next section, a review of strategy and personal values is presented, followed by the methods, results, discussion, implications, and study limitations.

\section{LITERATURE REVIEW}

\section{Strategy and Decision Making}

The relationship between strategy and organizational success cannot be undermined (Gruber, Heinemann, Brettel, \& Hungeling, 2010; Mintzberg, 1987; Pascale, 1984). Strategic decisions are generally made on the business and corporate levels (Bowman \& Helfat, 2001; Hofer \& Schendel, 1978). The latter is related to selecting an optimal set of businesses and making choices about how they should be integrated in the corporate whole, while the former is more concerned with how a firm creates a competitive advantage in each business (Dewit \& Meyer, 2010).

At the business level, Porter (1980) argued that all forms of competitive advantage can be grouped into two broad or generic categories, cost and differentiation strategies. Cost-based strategies focus on reducing overall costs to allow firms to compete on price, while differentiation strategies are concerned with providing distinctive product qualities. Despite criticisms (e.g. Baden-Fuller \& Stopford, 1992), Porter's conceptualization of generic strategies has received wide empirical support (Bowman \& Ambrosini, 1997; Campbell-Hunt, 2000; Dess \& Davis, 1984). Similarly, Treacy and Wiersema (1995) argued that there are three 
generic strategies to gain a competitive advantage including operational excellence (reliable, low-cost products), product leadership (differentiated, innovative products), and customer intimacy (client specific customized products). Like Porter, Treacy and Wiersema warned that firms should focus on one strategy for effective functioning, thus avoiding a mix of strategies. At the corporate level too, firms are faced with a number of strategic choices which aim to improve efficiency and profitability. At the corporate level, this includes diversification, integration, and acquisition strategies (Pheng \& Sirpal, 1995). Firms may diversify into related or unrelated products, integrate vertically into the supplier or buyer business, or merge or acquire other firms. Each of these choices has its own distinct implications for the organization (Hambrick \& Mason, 1984; Harrison \& Pelletier, 1995).

Indeed, some strategies have helped organizations make it to the peak, while other strategies have provided a recipe for disaster (Mintzberg, 1994). As decision makers, managers are at the heart of organizational choices (Collins \& Porras, 1995). The board of directors expects senior managers to make the best strategic choices in order to keep their organizations competitive. However, this is easier said than done, as managers are faced with many different internal and external variables which all enter the decision-making formula at the same time (Siggelkow \& Rivkin, 2005). For example, a recent study by Ashill and Jobber (2013) revealed that experience and personality variables (locus of control and tolerance for ambiguity) played a significant role in the type of perceived environment uncertainty experienced by decision makers. Another study by Anderson and McAdam (2006) showed that organizational size and sector have an impact on managers' strategic choices. Finally, a study by Ross and Wood (2008) demonstrated the way in which environmental laws and regulations influence capital investment decisions. In sum, numerous elements affect managerial decision making. Cognitive abilities (March \& Simon, 1958), previous experience and knowledge (Gioia, 1986; March \& Simon, 1958), and personal factors can all have an impact on a final strategic choice (Hambrick \& Mason, 1984). What managers face can be portrayed in what Mischel (1977) termed as a 'weak situation' in which there are too many stimuli that are complex and vague. Faced with such common weak situations, there are no absolute clear indicators regarding the ideal choice; instead, their personal experiences, knowledge, and personality come into play as managers figure out what to do (Finkelstein, et al., 2009: 44). In fact, the same situation can be acted upon very differently by different managers due to the wide variation in those variables (Hambrick, 1989). Based on the theory of bounded rationality (Cyert \& March, 1963), Hambrick (2007: 337), the following characteristics serve to filter and distort information in a three-step process: 
Executive experiences, values, and personalities affect managers' 1) field of vision (the directions in which they look and listen), 2) selective perception (what they actually see and hear), and 3 ) interpretation (how they attach meaning to what they see and hear).

\section{Values and Strategic Choices}

Value is defined 'as a broad tendency to prefer certain states of affairs over others' (Hofstede, 1980: 19). It is concerned with what a person regards as desirable and which factors influence his or her choices and decisions from among alternative courses of action. Having said this, values have an influence on human choices and behavior after all (Fritzsche, 1995; Fritzsche \& Oz, 2007; Rokeach, 1973). They serve as the foundation from which attitudes and behaviors are formed (Homer \& Kahle, 1988). As Rokeach (1968: 550) asserted, 'Once a value is internalized it becomes, unconsciously, a standard or criterion for guiding action.' According to the social adaptation theory (Kahle, 1983), values are types of social cognitions which help individuals adapt to their environment by behaving in different situations in line with their values. As each value is learned or adopted, it becomes part of the value system in which each value has its own amount of priority, forming a hierarchy of values which influences managerial choices according to the importance of each value (Hambrick \& Brandon, 1988).

Values are relatively enduring and stable in one's life compared to attitudes and emotions (Rokeach, 1973). Once learned, values become difficult to change (Bardi \& Goodwin, 2011). However, this is not to say that they are entirely fixed over one's life; special events and major life transitions on the cultural, societal, and personal experience levels may trigger rearrangements of value priorities (Rokeach, 1973; Bardi \& Goodwin, 2011) (see also Harrison, 1999). Values can originate from a number of sources, including national culture, regional society, religion, family, and firms (Finkelstein, et al., 2009). Examples of value dimensions include those relating to broad items such as collectivism, rationality, novelty, duty, materialism, and power (e.g. Hambrick \& Brandon, 1988).

According to Andrews (1980), personal values are presumed to have a significant relationship with strategic choices. He argues that strategy is a projection of preferences driven by the personal values of the individual. In their theory, Hambrick and Mason (1984) argue that personal values, as part of the psychological dimension, play a major role in influencing strategic choice. According to them, managers tend to choose strategies in line with their personal values which are assumed to enter directly into the selection equation or indirectly through its effect on managerial perceptions 
(Finkelstein, et al., 2009). According to Finkelstein and Hambrick (1996), values limit the manager's field of vision, influence their selective perception with respect to what they actually see and hear, and finally influence their interpretation of information which will all be reflected in the choices they make. Hambrick and Mason (1984: 195) imply that managers will discard certain choices that contradict their values. The researchers proposed that strategic decision making is a reflection of the manager's cognitive base, which is largely shaped by values.

In a similar vein, England (1967: 54) also argues that personal values have a strong influence on management behavior:

1. Personal value systems influence a manager's perception of the situations and problems he faces.

2. Personal value systems influence a manager's decisions and solutions to problems.

3. Personal value systems influence the way in which a manager looks at other individuals and groups of individuals; thus, they influence interpersonal relationships.

4. Personal value systems influence the perception of individual and organizational success as well as their achievement.

5. Personal value systems set the limits for the determination of what is and what is not determined as ethical behavior by a manager.

6. Personal value systems influence the extent to which a manager will accept or resist organizational pressures and goals.

Finally, the Harvard Policy Model (see for example Andrews, 1971; 1980) also argues for the importance of personal values on strategic action. In particular, Andrews (1980: 79) stated that:

We should in all realism admit that the personal desires, aspirations, and needs of the managers of a company actually do play an influential role in the determination of strategy. Against those who are offended by this idea either for its departure from the stereotype of single-minded economic man or for its implicit violation of responsibilities to the shareholder, we would argue that we must accept not only the inevitability but the desirability of this intervention.

Based on what has been discussed in the previous sections, the following hypotheses were developed:

Hypothesis 1: There is a significant relationship between personal values and preferences in business strategy. 
Hypothesis 2: There is a significant relationship between personal values and preferences in corporate strategy.

\section{METHODS}

\section{Respondents and Setting}

Given the inherent difficulties and challenges of accessing a large pool of senior managers who are actually willing to submit themselves to scholarly and psychological probing in strategic research, Hambrick (2007) argued that business students (e.g. MBA students) present a sensible alternative. Data was collected through questionnaires distributed at a renowned business school in the region. The students completed the questionnaires in class and returned them to the researcher. The total sample consisted of 137 graduate and senior undergraduate business students. As part of their curriculum and school policy, all students, regardless of their area of specialty, are obliged to enroll in strategic management. In other words, business students cannot graduate unless they pass the strategic management course, which is considered a senior course at this school. Having said this, the sample is presumed to be quite knowledgeable with all concepts of strategic management, given that they have all enrolled in the strategic management course at the school. Moreover, the graduate students are considered to be mature working professionals pursuing graduate studies in addition to their full-time jobs.

Regarding the sample description, tThe subjects were relatively balanced in terms of gender distribution, although the females were slightly fewer in number. In particular, $48 \%$ were females. Moreover, $30 \%$ of the sample were aged 31 and over, while the remaining were younger, aged between 21 to 30 years old. Finally, the majority of the participants were not married.

The questionnaire is made up of three main parts. The first part describes the demographic characteristics, including gender, age, and marital status. The second part is related to our two dependent variables: business strategy and corporate strategy. The questions assess the preferences of individuals related to business- and corporate-level strategies. The third part of the questionnaire involves the independent variable, which aims to measure the personal values of the respondents.

\section{Measures}

- Strategy

Based on the approach by Martin and Grbac (2003), the type of strategy was assessed with single items that provided a short description of each strategy. This is an 
established valid measurement method in strategic research (Conant, Mokwa, \& Varadarajan, 1990; James \& Hatten, 1995; Shortell \& Zajac, 1990), and it has been used in several recent studies (Slater \& Olson, 2000; Parnell, 2010; Pelham, 1999). Accordingly, the respondents were provided with short descriptions of the types of business and corporate strategies and were asked to select their preferred strategy. The business strategy choices included operational excellence, product leadership, and customer intimacy, while corporate strategy included integration and diversification strategies.

\section{- Personal values}

To measure personal values, a scale developed by McDonald and Gandz (1991; 1992) was used in this study. Unlike other value scales, the 24-personal value items of McDonald and Gandz are more suitable for use in a business context (McDonald \& Gandz, 1991). Following the approach used by Finegan (2000), participants were asked to rate the 24 values on a scale from 1 (not important) to 7 (very important). This scale had a test-retest reliability of .76 and an interrater reliability of .77. Both the convergent and discriminant validity are high (see McDonald, 1993).

\section{Procedure}

Discriminant analysis was performed to compare the groups on 24 personal value items established by McDonald and Gandz in order to assess the discriminating power of these items in predicting group membership in relation to strategic choice (for example, if groups who prefer operational excellence strategies can be differentiated from groups who prefer product leadership strategies). With respect to grouping, the study had two main groups, the business strategy group and the corporate strategy group, in line with the objective of this study. The corporate strategy group had two sub groups. Specifically, the business strategy group had three categories which were coded as follows: $1=$ operational excellence, 2 = product leadership, and $3=$ customer intimacy. The corporate strategy group had two sub groups: integration and diversification. The first sub group had two categories coded as $1=$ backward integration and 2 = forward integration. The other sub group had two categories as well, coded as $1=$ unrelated diversification and $2=$ related diversification.

The discriminant analysis was conducted using a stepwise entry (SPSS Release 20 ) to select the discriminating variables. The stepwise discriminant analysis is a useful method for selecting the best combination of discriminating variables, especially if the focus is of an exploratory nature (Klecka, 1980). 
The sample size of 137 respondents basically meets the recommended sample size to an estimated parameter ratio of 5 to 1 (Bentler \& Chou, 1987). Moreover, assumptions of multicolinearity, normality, linearity, and equal variance-covariance were met at acceptable levels.

\section{RESULTS}

Given that our data was based on self-report accounts, there might be a risk of common method bias. Harman's one-factor test (Harman, 1976), one of the most commonly used statistical techniques to identify common method bias (Podsakoff, MacKenzie, Lee, \& Podsakoff, 2003; Carr \& Kaynak, 2007), was performed. If the variability amount explained by the first factor exceeds 50 percent, it shows that there is a serious problem of common method bias. The first factor only accounted for 26.6 percent. Accordingly, no general factor was apparent (Harvey \& Martinko, 2009), and hence there was not a significant common method bias present in our sample.

\section{Business Strategy}

Step-wise discriminant analysis was run to determine the relative importance of each factor that best discriminates between the three business strategies. It follows that a significant $(\mathrm{p}<0.05)$ discriminant function was found, as can be seen in Table 1.

Table 1 Wilks' Lambda (business strategy)

\begin{tabular}{lllll}
\hline Test of Function(s) & $\begin{array}{l}\text { Wilks' } \\
\text { Lambda }\end{array}$ & Chi-square & df & Sig. \\
\hline 1 & .909 & 11.982 & 2 & .003 \\
\hline
\end{tabular}

The value 'obedience' was the item that appeared as a significant discriminator. The results of the stepwise discriminant analysis demonstrate this finding as shown in Table 2. The eigenvalue associated with this discriminant function is .101 (Table 3).

The canonical correlation coefficient, which is the measure of correlation between the discriminant scores and the group, is 0.302 . Moreover, when squared, the canonical correlation explains the variance in the dependent variable, and it indicates that $9 \%$ of the variance in business strategy orientation is explained by the model. In sum, strategic choice (operational excellence, product leadership, and customer intimacy) differed according to the personal values of the strategist/individual. Obedience, which is defined by McDonald and Gandz (1991) as complying with directions and conforming to rules, was able to differentiate between the three strategic orientations. Accordingly, the first hypothesis received some support in that 
strategic choices are influenced by personal values. By inspecting the group means (not shown here for space limitations), it follows that individuals who favor customer intimacy strategies tend to put the highest weight on obedience than the other two strategies. In other words, proponents of customer intimacy strategies possess values that reflect high respect for rules and policies according to this study.

Table 2 Stepwise Analysis (Business Strategy)

\begin{tabular}{|c|c|c|c|c|c|c|c|c|c|}
\hline \multirow{3}{*}{ Step } & \multirow{3}{*}{ Entered } & \multicolumn{8}{|c|}{ Wilks' Lambda } \\
\hline & & \multirow[t]{2}{*}{ Statistic } & \multirow[t]{2}{*}{ df1 } & \multirow[t]{2}{*}{ df2 } & \multirow[t]{2}{*}{ df3 } & \multicolumn{4}{|l|}{ Exact $\mathrm{F}$} \\
\hline & & & & & & Statistic & df1 & $\mathrm{df} 2$ & Sig. \\
\hline 1 & obedience & .909 & 1 & 2 & 125.000 & 6.287 & 2 & 125 & .003 \\
\hline
\end{tabular}

Table 3 Eigenvalue (Business Strategy)

\begin{tabular}{lllll}
\hline Function & Eigenvalue & $\%$ of Variance & Cumulative \% & $\begin{array}{l}\text { Canonical } \\
\text { Correlation }\end{array}$ \\
\hline 1 & $.101^{\mathrm{a}}$ & 100.0 & 100.0 & .302 \\
\hline
\end{tabular}

\section{Corporate Strategy}

With respect to corporate integration strategies, the results show that one significant discriminant function was obtained, accounting for $16 \%$ of between-group variability (see Table 4).

Table 4 - Eigenvalue (Integration Strategy)

\begin{tabular}{lllll}
\hline Function & Eigenvalue & \% of Variance & Cumulative \% & $\begin{array}{l}\text { Canonical } \\
\text { Correlation }\end{array}$ \\
\hline 1 & .069 & 100.0 & 100.0 & .253 \\
\hline
\end{tabular}

Values The values of 'courtesy' and 'adaptability' were the two items that appeared as significant discriminators (see Table 5).

The structure matrix (Table 6) shows the correlations of each variable with the discriminate function (Pearson coefficients): courtesy (.717) and adaptability (-.400). 
Table 5 - Stepwise Statistics (Integration Strategy)

\begin{tabular}{|c|c|c|c|c|c|c|c|c|c|}
\hline \multirow{3}{*}{ Step } & \multirow{3}{*}{ Entered } & \multicolumn{8}{|c|}{ Wilks' Lambda } \\
\hline & & \multirow[t]{2}{*}{ Statistic } & \multirow[t]{2}{*}{ df1 } & \multirow[t]{2}{*}{$\mathrm{df} 2$} & \multirow[t]{2}{*}{ df3 } & \multicolumn{4}{|l|}{ Exact $\mathrm{F}$} \\
\hline & & & & & & Statistic & df1 & $\mathrm{df} 2$ & Sig. \\
\hline 1 & courtesy & .966 & 1 & 1 & 126 & 4.435 & 1 & 126 & .037 \\
\hline 2 & adaptability & .936 & 2 & 1 & 126 & 4.283 & 2 & 125 & .016 \\
\hline
\end{tabular}

Table 6 Structure Matrix (Integration Strategy)

\begin{tabular}{ll}
\hline & Function 1 \\
\hline courtesy &. $\mathbf{7 1 7}$ \\
consideration & .444 \\
adaptability & -.400 \\
cooperation & .340 \\
forgiveness & .292 \\
socialequality & .259 \\
formality & .224 \\
humor & .217 \\
openness & .216 \\
fairness & .210 \\
moralintegrity & .205 \\
obedience & .186 \\
development & .184 \\
creativity & .153 \\
broadmindedness & .113 \\
cautiousness & .104 \\
autonomy & .100 \\
diligence & .090 \\
aggressiveness & -.083 \\
orderliness & .070 \\
initiative & .068 \\
experimentation & .063 \\
logic & .053 \\
economy & .020 \\
\hline
\end{tabular}

In sum, the results show some support for hypothesis 2 on corporate strategy. Individuals who favor backward integration tend to differ from persons who chose 
forward integration, in terms of the personal values. This indicates that personal values do play a role in strategic choice relating to corporate strategy.

Moreover, as previously indicted, adaptability also appeared to be a differentiating dimension, although with a significantly smaller discriminating power than courtesy. Based on the group means (not shown here), forward integration strategies was favored more by decision makers who placed greater weight on 'adaptability.'

\section{Diversification}

The diversification dimension under corporate strategy was also studied in a stepwise discriminant analysis. The results, however, failed to show any support for the proposed assumption that personal values impact diversification choices (see Table 7).

Table 7 Wilk's Lambda (diversification strategy)

\begin{tabular}{lllll}
\hline Test of Function(s) & Wilks' Lambda & Chi-square & df & Sig. \\
\hline 1 & .842 & 19.466 & 24 & .727 \\
\hline
\end{tabular}

\section{DISCUSSION AND MANAGEMENT IMPLICATIONS}

The purpose of the study was to assess whether personal values had an effect on the choices in business and corporate strategies. The results here showed that personal values influenced strategic preferences. This reinforces previous theories and works which state that personal values have a strong impact on human behavior and decision making (Steptoe-Warren, Howat, \& Hume, 2011; Hambrick \& Mason, 1984; England, 1967).

In this study, individuals who favored customer intimacy strategies tend to place the highest weight on personal values related to obedience than the other two strategies. In other words, proponents of customer intimacy strategies possess values that reflect high respect for corporate laws and policies according to this study. Holding all else constant, for companies that want to offer a highly-customized product for its customer group requires its employees and managers to fully abide by the company standards and policies that were principally established to meet the customers' unique demands. In fact, compared to other types of companies, offering a tailored product to the customers, as this strategy entails (Treacy \& Wiersema, 1993), dictates that such companies invest heavily in marketing mechanisms to heed and follow their customer demands accurately (e.g. Berry \& Parasuraman, 1997; Mukerjee, 2013; Gulati \& Oldroyd, 2005). This feeds into the creation of corporate standards and policies to 
meet those expectations. In turn, the success of this strategy strongly relies on individuals who are willing to show full obedience to the standards and policies of the company.

With respect to corporate strategies, the findings also demonstrate that personal values have an impact. Individuals who chose backward integration are more likely to be courteous than individuals who prefer forward integration. It may be difficult to justify the reason for this finding; however, one explanation is that courteous individuals may identify more with an introvert personality profile (Myers, 1998). Hence, such individuals may prefer to deal with 'back-office' operations rather than dealing with the customer and the retail side of the business common to forward integration (Harrigan, 2003), which tends to fit more with an outgoing extrovert character (Vinchur, Schippmann, Switzer, \& Roth, 1998).

On the other hand, it does appear that individuals who place greater weight on 'adaptability' tend to prefer forward integration strategies which normally involve the retail and customer side of the business, compared to decision makers who favored backward integration, which is usually more concerned with the supplier and manufacturing side of the business. It can be argued that backward integration may impair organizational flexibility by often requiring heavy investment in expensive production assets that might be hard to sell, especially in scenarios that call for continuous changes (Hunger \& Wheelen, 2010; O'Shaughnessy, 1995) and therefore might not fit well with the profile of individuals who prefer more flexible strategies.

Finally, regarding corporate strategies related to diversification types, none of the 24 value items differentiated between related and unrelated diversification. There may be a number of reasons for this finding. It could be said that factors other than personal values might be more strongly associated with diversification strategies (i.e. related vs. unrelated diversification). Although values have a strong impact on decision making (Hambrick \& Mason, 1987), decision making is a complex issue that is influenced by numerous variables (Papadakis, et al., 1998). Future research could investigate the impact of values and other psychological dimensions such as personality, for example, on the choices in diversification strategies. An alternative explanation to this result might be related to the small sample size, which is explained in more detail in the limitations section.

The findings attained in this paper offer vital implications for organizations. First, it suggests that firms which follow any of the three generic business strategies may find it useful to hire individuals who possess personal values that support or match the espoused strategy in the firm. For example, firms which tend to customize or tailor their products (customer intimacy strategy) such as Dell may need to hire 
individuals who possess values related to obedience according to this study. In fact, some academics have proposed 'Management by Values', as an emerging management tool (Dolan et al., 2006). The authors emphasize the importance of recruiting and selecting individuals with values that are in tune with organizational needs and strategies.

This study is the first empirical article that examines the role of personal values in strategic choices involving both business and corporate strategies that researchers have long called for (Hambrick \& Mason, 1984). However, it must be cautioned that this research was mainly exploratory. Although the findings confirmed the importance of personal values in strategic preferences, more research in this area is required. Given the significance of strategic decisions by decision makers in the success of the firm, understanding the relationship between personal values of decision makers and strategic choices promises a rich agenda for corporate effectiveness. Further research is needed to increase our knowledge in this vital area related to personal values and strategic choice (Hambrick, 2007). Strategic choices may cover various aspects including integration, diversification, response time, and other factors which can all be measured in different ways and which present important avenues for future research in understanding the relationship between such strategic factors and personal values (Don Hambrick, personal communication, March 8, 2013).

\section{LIMITATIONS}

One of the major limitations of this study is the sample size. Although this research has assured the suggested minimum of 5 to 1 ratio for discriminant analysis, researchers argue for higher observations for each independent variable for better results. Accordingly, the small sample size with a fairly large number of value items (24 values) entered into the model may have served to reduce the statistical power of our analysis; hence, this may have obscured the influence of additional personal values in the model. For example, the study showed that 'obedience' was the only item that appeared as a significant discriminator between the three types of business strategies. Therefore, the author strongly suggests that this study be replicated with bigger sample sizes in order to generalize the findings more confidently and uncover the effects of additional personal values. However, as far as this study is concerned, statistical assumptions regarding discriminant analysis were met at acceptable levels.

Another limitation is that the analysis did not include demographic variables in the model as potential confounding variables. The rationale for this is that increasing the predictor variables (i.e. demographic variables) may further reduce the power of 
our tool for a small sample size such as this one. Future research should address this issue.

Finally, the research has been limited to business students. Surveying managers is perhaps a sensible alternative for future studies, given that managers can provide a better representative sample, and hence the results can be generalized with more confidence to that population. Nevertheless, all of the respondents in this study are considered familiar with the area of strategies, as was explained in the respondents and setting section of this paper. Moreover, some of the respondents are considered to be mature working professionals. Furthermore, in line with Hambrick's (2007) research suggestions, surveying professional business students (e.g. MBA students) is recommended in such types of strategic research given the challenges in subjecting senior executives to psychological probing. In fact, there is a strong case to research and learn about the values of business students, who are the future leaders of organizations, as their values tend to influence their behavior and thus the direction of businesses and organizations in the future (Giacomino, Brown, \& Akers, 2011).

\section{REFERENCES}

Anderson, K., \& McAdam, R. (2006). Choosing the best business improvement strategy: the effects of organizational size \& sector on management decisionmaking. Journal of General Management, 32(1), 13-29.

Andrews, K.R. (1971). The concept of corporate strategy. Homewood, IL: Dow Jones - Irwin.

Andrews, K.R. (1980). The concept of corporate strategy. Homewood, IL: Dow Jones - Irwin.

Ashill, N. J., \& Jobber, D. (2013). The effects of experience on managerial decision-making uncertainty. Journal of General Management, 39(1), 81-110.

Baden-Fuller, C., \& Stopford, J. M. (1992). Rejuvenating the mature business: the competitive challenge. London: Routledge.

Bantel, K.A., \& Jackson, S.E. (1989). Top management \& innovations in banking: Does the composition of the top team make a difference. Strategic Management Journal, 10(2), 107-124. http://dx.doi.org/10.1002/smj.4250100709

Bardi, A., \& Goodwin, R. (2011). The dual route to value change: Individual processes and cultural moderators. Journal of Cross-Cultural Psychology, 42, 271-287. http://dx.doi.org/10.1177/0022022110396916

Bentler, P.M., \& Chou, C.P. (1987). Practical issues in structural modeling. Sociological Methods \& Research, 16(1), 78-117. http://dx.doi.org/10.1177/0049124187016001004 
Berry, L.L., \& Parasuraman, A. (1997). Listening to the customer - the concept of a service-quality information system. Sloan Management Review, Spring, 65-76.

Bowman E.H., \& Helfat, C.E. (2001). Does corporate strategy matter? Strategic Management Journal, 22(1), 1-23.

Bowman, C., \& Ambrosini, V. (1997). Perceptions of strategic priorities, consensus, $\&$ firm performance. Journal of Management Studies, 34(2), 241-258.

Campbell-Hunt, C. (2000). What have we learned about generic competitive strategy? A meta-analysis. Strategic Management Journal, 21, 127-154.

Brouthers, K.D., Brouthers, L.E., \& Werner, S. (2000). Influences on strategic decision-making in the Dutch financial services industry. Journal of Management, 26(5), 863 -883. http://dx.doi.org/10.1177/014920630002600506

Carpenter, M. A., Geletkanycz, M.A., \& Sanders, W.G. (2004). Upper echelons research revisited: Antecedents, elements \& consequences of top management team composition. Journal of Management, 30(6), 749-78. http://dx.doi.org/10.1016/j.jm.2004.06.001

Carr, A.S., \& Kaynak, H. (2007). Communication methods, information sharing, Supplier development and performance. International Journal of Operations \& Production Management, 27, 346-370. http://dx.doi.org/10.1108/01443570710736958

Chatterjee, A., \& Hambrick, D. (2007). It's all about me: Narcissistic chief executive officers \& their effects on company strategy \& performance. Administrative Science Quarterly, 52, 351-386.

Child, J. (1972). Organizational Structure, environment \& performance: the role of $\begin{array}{llll}\text { strategic choice, } & \text { Sociology. } & 6(1), & 1-22 .\end{array}$ http://dx.doi.org/10.1177/003803857200600101

Collins, J., \& Porras, T. (1995). Building your company's vision. Harvard Business Review, 74(5), 65-77.

Conant, J.S., Mokwa, M.P., \& Varadarajan, P.R. (1990). Strategic types, distinctive marketing competencies \& organizational performance: a multiple measures based study. Strategic Management Journal, 11(5), 365-83. http://dx.doi.org/10.1002/smj.4250110504

Cyert, R., \& March, J.G. (1963). A behavioral theory of the firm. Oxford: Blackwell.

De Wit, B., \& Meyer, R. (2010). Strategy synthesis: resolving strategy paradoxes to create competitive advantage. London: Thomson Learning.

Dess, G.G., \& Davis, P.S. (1984). Porter's (1980) generic strategies as determinants of strategic group membership \& organizational performance. Academy of Management Journal, 27(3), 467-488. 
Dolan, S., Garcia, S., \& Richley, B. (2006). Managing by values: A corporate guide to living, being alive, \& making a living in the 21st century. New York: Palgrave Macmillan. http://dx.doi.org/10.1057/9780230597754

Eisenhardt, K., \& Zbaracki, M. (1992). Strategic decision making. Strategic Management Journal, 13, 17-37. http://dx.doi.org/10.1002/smj.4250130904

Elbanna, S., \& Child, J. (2007). The influence of decision, environmental \& firm characteristics on the rationality of strategic decision-making. Journal of Management Studies, 44(4), 561-91. http://dx.doi.org/10.1111/j.14676486.2006.00670.x

England, G.W. (1967). Personal value systems of American managers. Academy of Management Journal, 19, 53-68. http://dx.doi.org/10.2307/255244

Finegan, J.E. (2000). The impact of person \& organizational values on organizational commitment. Journal of Occupational \& Organizational Psychology, 73, 149169. http://dx.doi.org/10.1348/096317900166958

Finkelstein, S., \& Hambrick, D. (1996). Strategic leadership: Top executives \& their effects on organizations. St Paul, MN: West Publishing Company.

Finkelstein S., Hambrick, D.C., \& Cannella, A.A. (2009). Strategic leadership: Theory \& research on executives, top management teams \& boards. New York: Oxford University Press.

Fritzsche, DJ. (1995). Personal values: Potential keys to ethical decision making. Journal of Business Ethics, 14, 909-22. http://dx.doi.org/10.1007/BF00882069

Fritzsche, D., \& Oz, E. (2007). Personal values' influence on the ethical dimension of decision making. Journal of Business Ethics, 75(4), 335-344. http://dx.doi.org/10.1007/s10551-006-9256-5

Giacomino, D. E., Brown, J., \& Akers, M. D. (2011). Generational differences of personal values of business students. American Journal of Business Education, 4(9), 19-30.

Gioia, D.A., \& Chittipeddi, K. (1991). Sense making \& sense giving in strategic change initiation. Strategic Management Journal, 12(6), 433-48. http://dx.doi.org/10.1002/smj.4250120604

Gruber, M., Heinemann, F., Brettel, M., \& Hungeling, S. (2010). Configurations of resources \& capabilities \& their performance implications: An exploratory study on technology ventures. Strategic Management Journal, 31(12), 1337 - 56. http://dx.doi.org/10.1002/smj.865

Gulati, R., \& Oldroyd, J.B. (2005). The Quest for Customer Focus. Harvard Business Review, 83, 92-1. 
Gupta, A.K., \& Govindarajan, V. (1984). Business unit strategy, managerial characteristics, \& business unit effectiveness at strategy implementation. Academy of Management Journal, 27, 25-41. http://dx.doi.org/10.2307/255955

Hambrick, D. (2007). Upper echelon theory: Revisited. Academy of Management Review, 32(2), 343.

Hambrick, D.C., \& Brandon, G. L. (1988). Executive values. In D.C. Hambrick (Ed.), Executive effectiveness, concepts \& methods for studying top managers (pp. 334). Greenwich, CT: JAI Press.

Hambrick, D., \& Mason, P. (1984). Upper echelons: The organization as a reflection of its top managers. Academy of Management Review, 9(2), 193-206. http://dx.doi.org/10.2307/258434

Hambrick, D.C. (1989). Guest editor's introduction: Putting top managers back in the strategy picture. Strategic Management Review, 10, 5-15. http://dx.doi.org/10.1002/smj.4250100703

Harrigan, K. (2003). Vertical integration, outsourcing, \& corporate strategy. NY: Beard Books.

Harrison, E.F., \& Pelletier, M.A. (1995). A paradigm for strategic decision success, Management Decision. 33, 53-59. http://dx.doi.org/10.1108/00251749510090593

Harman, H.H. (1976). Modern factor analysis (3rd ed.). Chicago: University of Chicago Press.

Harvey, P., \& Martinko, MJ. (2009). An empirical examination of the role of attributions in psychological entitlement and its outcomes. Journal of Organizational Behavior, 30, 459-476.

Hiller, N., \& Hambrick, D. (2005). Conceptualizing executive hubris: The role of (hyper) core self-evaluations in strategic decision-making. Strategic Management Journal, 26, 297-319. http://dx.doi.org/10.1002/smj.455

Hitt, M. A., \& Tyler, B. B. (1991). Strategic decision models: Integrating different perspectives. Strategic Management Journal, 12(5), 327-351. http://dx.doi.org/10.1002/smj.4250120502

Hitt, M.A., Keats, B.W., \& DeMarie, S. (1998). Navigating in the new competitive landscape: Building strategic flexibility \& competitive advantage in the twentyfirst century. Academy of Management Executive, 12(4), 2242.

Hofer, C.W., \& Schendel, D.E. (1978). Strategy formulation: Analytical concepts. St. Paul: West Publishing.

Hofstede, G. (1980). Culture's consequences: International differences in workrelated values. London: Sage Publications. 
Homer, P.M., \& Kahle, L.R. (1988). A structural equation test of the value-attitudebehavior hierarchy. Journal of Personality \& Social Psychology, 54(4), 638-46.

Hunger, J.D., \& Wheelen, T.L. (2010). Essentials of strategic management. Upper Saddle River, NJ: Pearson Prentice-Hall.

James, W.L., \& Hatten, K.J. (1995). Further evidence on the validity of the self-typing paragraph approach: Miles \& Snow strategic archetypes in banking. Strategic Management Journal, 16, 161- 8. http://dx.doi.org/10.1002/smj.4250160206

Kahle, L.R. (1983), Social values \& social change: Adaptation to life in America. New York: Praeger.

Klecka, W.R. (1980). Discriminant analysis. Newbury Park, CA: Sage.

Kotey, B., \& Meredith, G. (1997). Relationship among owner/manager personal values, business strategies, \& enterprise performance. Journal of Small Business Management, 35(2), 37 - 64.

Lawrence, B.S. (1997). The black box of organizational demography. Organization Science, 8, 1-22.

Lee, D., Newman, P., \& Price, R. (1999). Decision making in organizations. Glasgow: Prentice Hall.

March, J., \& Simon, H. (1958). Organizations. New York: Wiley.

Martin, J., \& Grbac, B. (2003). Using supply chain management to leverage a firm's market orientation. Industrial Marketing Management, 32(1), 25-49.

McDonald, P., \& Gandz, J. (1991). Identification of values relevant to business research. Human Resource Management, 30, 217- 236. http://dx.doi.org/10.1002/hrm.3930300205

McDonald, P., \& Gandz, J. (1992). Getting value from shared values. Organizational Dynamics, 20, 64-77. http://dx.doi.org/10.1016/0090-2616(92)90025-I

McDonald, P. (1993). Individual-organizational value congruence: Operationalization \& consequents. Unpublished doctoral dissertation, University of Western Ontario, Canada.

Miller, D., Kets de Vries, M.F.R., \& Toulouse, J.M. (1982). Top executive locus of control \& its relationship to strategy-making, structure, \& environment. Academy of Management Journal, 25(2), 237-253. http://dx.doi.org/10.2307/255988

Mintzberg, H. (1987). The strategy concept ii: another look at why organizations need strategies. California Management Review, 30, 25-32. http://dx.doi.org/10.2307/41165264

Mintzberg, H. (1994), The rise \& fall of strategic planning. New York: The Free Press. 
Mischel, W. (1977). The interaction of person \& situation. In D. Magnusson, \& N. S. Endler (Eds.), Personality at the cross-rods: Current issues in interactional psychology (pp. 333-352). Hillsdale, NJ.: Lawrence Erlbaum.

Mukerjee, K. (2013). Customer-oriented organizations: A framework for innovation. The Journal of Business Strategy, 34(3), 49-56. http://dx.doi.org/10.1108/JBS-Jun-2012-0013

Myers, I.B. (1998). Introduction to type: A guide to understanding your results on the Myers Briggs type indicator. Palo Alto, CA: Consulting Psychologists Press.

Nadkarni, S., \& Herrmann, P. (2010). CEO personality, strategic flexibility, \& firm performance: The case of the Indian business process outsourcing industry. Academy of Management Journal, 53(5), 1050-1073. http://dx.doi.org/10.5465/AMJ.2010.54533196

O'Shaughnessy, J. (1995). Competitive marketing: A strategic approach. London Routledge.

Pant, P. N., \& Lachman, R. (1998). Value incongruity \& strategic choice. Journal of Management Studies, 35, 195-212. http://dx.doi.org/10.1111/1467-6486.00090

Papadakis, V.M., Lioukas, S., \& Chambers, D. (1998). Strategic decision-making processes: the role of management \& context. Strategic Management Journal, 19(2). http://dx.doi.org/10.1002/(SICI)1097-0266(199802)19:2\%3C115::AIDSMJ941\%3E3.0.CO;2-5

Parnell, J.A. (2010). Strategic clarity, business strategy \& performance. Journal of $\begin{array}{llll}\text { Strategy } \quad \text { \& } & \text { Management, }\end{array}$ http://dx.doi.org/10.1108/17554251011092683

Pascale, R.T. (1984). Perspective on strategy: the real story behind Honda's success. California Management Review, 26, 47-72. http://dx.doi.org/10.2307/41165080

Pelham, A.M. (1999). Influence of environment, strategy, \& market orientation on performance in small manufacturing firms. Journal of Business Research, 45(1), 33-46. http://dx.doi.org/10.1016/S0148-2963(98)00026-5

Peterson, R.S., Smith, D.B., Martorana, P.V., \& Owens, P.D. (2003). The impact of chief executive officer personality on top management team dynamics: One mechanism by which leadership affects organizational performance. Journal of Applied Psychology, 88, 795-808. http://dx.doi.org/10.1037/0021-9010.88.5.795 Pheng, L. S., \& Sirpal, R. (1995). Western generic business \& corporate strategies: Lessons from the thirty-six Chinese classical strategies of war. Marketing Intelligence $\&$ Planning, 13(6), 34. http://dx.doi.org/10.1108/02634509510094174 
Podsakoff, P.M., MacKenzie, S.B., Lee, J-Y., \& Podsakoff, N.P. (2003). Common method biases in behavioral research: a critical review of the literature and recommended remedies. Journal of Applied Psychology, 88, 879-903. http://dx.doi.org/10.1037/0021-9010.88.5.879

Porter, M. (1980). Competitive strategy: Techniques for analyzing industries \& competitors. New York: The Free press. http://dx.doi.org/10.1108/eb025476

Rahman, N., \& De Feis, G. L. (2009). Strategic decision-making: Models \& methods in the face of complexity \& time pressure. Journal of General Management, 35(2), 43-60.

Rokeach, M. (1968). Beliefs, attitudes, \& values. San Francisco, CA: Jossey-Bass.

Rokeach, M. (1973). The nature of human values. New York: Free Press.

Ross, D. G., \& Wood, D. (2008). Do environmental social controls matter to Australian capital investment decision-making? Business Strategy \& The Environment, 17(5), 294-303. http://dx.doi.org/10.1002/bse.622

Shivakumar, R. (2014). How to tell which decisions are strategic. California Management Review, 56(3), 78. http://dx.doi.org/10.1525/cmr.2014.56.3.78

Siggelkow, N., \& Rivkin, J. (2005). Speed \& search: Design organizations for turbulence \& complexity. Organizational Science, 16(2), 101-122. http://dx.doi.org/10.1287/orsc.1050.0116

Shortell, Stephen M., \& Zajac, Edward J. (1990). Perceptual \& archival measures of Miles \& Snow's strategic types: a comprehensive assessment of reliability \& validity. Academy of Management Journal, 33(4), 817-832. http://dx.doi.org/10.2307/256292

Slater, S.F., \& Olson, E.M. (2000). Strategy type \& performance: the influence of salesforce management. Strategic Management Journal, 21(2), 813-29. http://dx.doi.org/10.1002/1097-0266(200008)21:8\%3C813::AID-SMJ122\%3E3.3.CO;2-7

Steptoe-Warren, G., Howat, D., \& Hume, I. (2011). Strategic thinking \& decision making: Literature review. Journal of Strategy \& Management, 4(3), 238-250

Treacy, M., \& Wiersema, F. (1995). The discipline of market leaders: Choose your customers, narrow your focus, dominate your market. Reading, MA: Addison Wesley.

Treacy, M., \& Wiersema, F. (1993). Customer intimacy \& other value disciplines.Harvard Business Review, 17(1), 84-93.

Vinchur, A.J., Schippmann, J.S., Switzer, F.S., \& Roth, P.L. (1998). A meta-analytic review of predictors of job performance for salespeople. Journal of Applied Psychology, 83, 586-597. 
